\title{
Stomatologiczna opieka zdrowotna nad dziećmi w Zielonej Górze w latach 1950-1989
}

\section{Pedodontic healthcare in Zielona Góra in 1950-1989}

\author{
Jacek Kotuła ${ }^{\boxplus}$, Andrzej Kierzek² \\ ${ }^{1}$ Specjalistyczny Gabinet Stomatologiczny, ul. Kardynała Stefana Wyszyńskiego 1, 65-525 Zielona Góra \\ Specialist Dental Practice \\ ${ }^{2}$ Karkonoska Państwowa Szkoła Wyższa, Zakład Fizjoterapii, ul. Lwówecka 18, 58-503 Jelenia Góra 5 \\ Karkonosze College in Jelenia Góra, Department of Physiotherapy \\ $\triangle$ j_kotula@poczta.onet.pl
}

\begin{abstract}
The interest in pedodontics began in the early $20^{\text {th }}$ century. In USA George Eastman was the first to propose the locating of dental clinics for children in schools. Despite the debacle of the project caused by the shortage of funds, his idea found followers. One of them was Ernst Jessen, who in Strasburg created the first free dental clinic for children in Europe. In Poland in 1912, in Cracow, on the initiative of Tomasz Janiszewski, DDS, the first dental ambulatories for poor children were established. In 1916 the Town Dental Ambulatory for poor children in Cracow released a brochure which pointed out the need for preventing caries, and dental treatment, among their fundamental roles for general human health. In Zielona Góra the organization of the healthcare system after the second world war involved the implementation of the modified Siemaszko model of healthcare based on public and free access to healthcare services for all people.

Free dental healthcare for children was provided by dental clinics established to serve schools. Pedodontics was focused on planned
\end{abstract}

treatment, fluoride prophylactics and health promotion in clinics operating in schools and preschools.

Paediatric dentistry was supported by developing orthodontic clinics. They dealt with orthodontic prophylaxis in preschools, and offered treatment using mobile dental braces in town, regional and provincial clinics.

Pedodontics developed in times when the need for dental healthcare among the public was great and unsatisfied, and despite a serious shortage of dentists, the range of offered dental procedures continued to extend. Because of the lack of appropriate financing dentists worked in difficult conditions and were unable to satisfy the needs of town residents. Dental healthcare was organised according to the three-tier reference system of medical care institutions.

Keywords: history of stomatology; history of dental treatment in Zielona Góra; pedodontic.

\begin{abstract}
ABSTRAKT
Zainteresowanie stomatologią dziecięcą sięga początku XX w. W USA Georg Eastman jako pierwszy zaproponował umieszczenie gabinetu stomatologicznego dla dzieci w szkole. Pomimo fiaska projektu związanego z brakami finansowymi znalazł on naśladowców. Jednym z nich był Ernst Jessen, który w Strasburgu utworzył pierwszą w Europie bezpłatną przychodnię stomatologiczną dla dzieci. W Polsce w 1912 r. z inicjatywy docenta Tomasza Janiszewskiego w Krakowie powstały pierwsze ambulatoria dentystyczne dla ubogich dzieci. W 1916 r. została wydrukowana przez Miejskie Ambulatorium Dentystyczne w Krakowie broszura dla ubogich dzieci, w której zwrócono uwagę m.in. na konieczność profilaktyki próchnicy i leczenia zębów w związku z ich kardynalnym znaczeniem dla ogólnego stanu zdrowia człowieka.

Organizacja systemu opieki zdrowotnej w okresie powojennym na terenie Zielonej Góry wiązała się z implementacją do polskich warunków modyfikacji siemaszkowskiego modelu opieki zdrowotnej opartego na powszechnym i bezpłatnym dostępie do świadczeń opieki zdrowotnej całego społeczeństwa.
\end{abstract}

Wprowadzenie bezpłatnej stomatologicznej opieki zdrowotnej nad dziećmi wiązało się z funkcjonowaniem szkolnych i międzyszkolnych poradni stomatologicznych. Stomatologia dziecięca wiązała się z prowadzeniem leczenia planowego, profilaktyki fluorkowej i promocji zdrowia w poradniach zlokalizowanych w szkołach i przedszkolach.

Pedodoncja była wspomagana przez rozwijające się poradnie ortodontyczne. Prowadziły one profilaktykę ortodontyczną w przedszkolach oraz leczenie aparatami ruchomymi w poradniach miejskich, obwodowych i wojewódzkich.

Rozwój stomatologicznej opieki zdrowotnej nad dziećmi odbywał się w warunkach ogromnego, niezaspokojonego zapotrzebowania społecznego na pomoc dentystyczną, dużego deficytu lekarzy stomatologów oraz stale powiększającego się zakresu świadczeń stomatologicznych. Brak odpowiedniego finansowania wpływał na trudne warunki pracy lekarzy dentystów i brak możliwości zaspokojenia potrzeb mieszkańców miasta. Stomatologiczna opieka zdrowotna wpisywała się w trójstopniowy podział referencyjności placówek medycznych.

Słowa kluczowe: historia stomatologii; historia lecznictwa stomatologicznego w Zielonej Górze; stomatologia dziecięca. 
Szybko rozprzestrzeniająca się choroba próchnicowa oraz jej powikłania ogólnoustrojowe u dzieci to podstawy tworzenia pierwszych poradni i gabinetów stomatologicznych dla tej części populacji. Na początku XX w. w Stanach Zjednoczonych lekarze dentyści, doceniając wagę profilaktyki, proponowali lokalizowanie gabinetów stomatologicznych dla dzieci w szkołach i przedszkolach. W 1909 r. Georg Eastman (1854-1932) w miejscowości Rochester w USA zaproponował zorganizowanie po raz pierwszy w szkole gabinetu stomatologicznego dla dzieci. Projekt nie doczekał się realizacji w związku z wysokimi kosztami, jednakże jego koncepcja w późniejszym okresie stała się podstawą do organizacji szkolnych i międzyszkolnych poradni stomatologicznych [1]. Pierwsza bezpłatna przychodnia stomatologiczna dla dzieci w Europie została założona przez Ernsta Jessena (1859-1933) w Strasburgu [1].

Problematyka szerokiej opieki stomatologicznej nad dziećmi na terenach polskich podejmowana była już w 1912 r. Z inicjatywy docenta dra Tomasza Janiszewskiego (1867-1939) powstały wówczas w Krakowie pierwsze ambulatoria dentystyczne dla ubogich dzieci szkolnych. Powołane zostały nie tylko w celu uśmierzania bólu, leczenia powikłań i próchnicy zębów, lecz także profilaktyki realizowanej poprzez naukę dzieci elementarnych zasad higieny jamy ustnej. W rozumieniu dra Janiszewskiego właśnie szkoła i grono nauczycielskie stanowiły realną możliwość nauczenia dzieci zasad prawidłowego szczotkowania zębów i wychowania w trosce o utrzymanie prawidłowej higieny jamy ustnej [2]. Drugą grupą zainteresowaną krzewieniem prawidłowych nawyków odnoszących się do stanu zdrowia jamy ustnej dzieci byli rodzice. W rozumieniu dentysty to właśnie rodzice mieli wzbudzać w dzieciach poczucie zaufania do ambulatorium dentystycznego poprzez systematyczne wizyty kontrolne połączone $\mathrm{z}$ badaniem jamy ustnej dzieci i leczeniem zębów objętych procesem próchnicowym [2].

W sierpniu 1916 r. w Krakowie miejski dentysta dr Ludwik Grabczak (ur. w 1886 r.) [3] opublikował broszurę dla ubogich dzieci szkolnych wydaną przez Miejskie Ambulatorium Dentystyczne, w której określał szerzącą się próchnicę zębów jako chorobę cywilizacyjną. Jego pierwszym wnioskiem odnośnie do problemu próchnicy był brak znajomości budowy i przeznaczenia zębów, które były traktowane jako estetyczna oprawa ust i dziąseł. Autor przekonywał o roli, jaką zęby odgrywają w zdrowym ciele. Podkreślał ich funkcję przy rozdrabnianiu pokarmów i wstępnym trawieniu w obrębie jamy ustnej i trawieniu w dalszych częściach przewodu pokarmowego [3]. Podnosił, iż jama ustna stanowi wrota wniknięcia zakażenia do całego ustroju, dlatego musi być stale utrzymywana w należytym porządku, gdyż zdrowa jama ustna chroni przed chorobami zakaźnymi [3].

Zmiany legislacyjne wprowadzone w ustawodawstwie polskim po II wojnie światowej były spowodowane uchwaleniem ustawy o zakładach społecznej służby zdrowia i planowej gospodarce w służbie zdrowia. Wpłynęły one na przejęcie przez państwo pełnej odpowiedzialności za zdrowie obywateli [4]. Tworzony system organizacji ochrony zdrowia oparty był na implementowanym do polskich realiów radzieckim modelu Siemaszki [5]. Był to system „budżetowy”, w którym zadania dotyczące opieki zdrowotnej realizowane były z wpływających do skarbu państwa podatków [6]. Cechowały go centralne planowanie i zarządzanie jednostkami organizacyjnymi służby zdrowia. Realizacja celów nie wiązała się z analizą potrzeb populacji lokalnej, lecz była oparta na przesłankach ideologicznych. Priorytetem systemu ochrony zdrowia było objęcie państwową, bezpłatną i kompleksową opieką zdrowotną wszystkich mieszkańców kraju. Cechami charakterystycznymi były również [5]: brak sektora prywatnego [7], uzależnienie prawa do świadczeń zdrowotnych od statusu zatrudnienia oraz zatrudnianie lekarzy na państwowych etatach [5]. Polska modyfikacja oryginalnego systemu radzieckiego polegała na dopuszczeniu do funkcjonowania praktyk gabinetów prywatnych, szczególnie w dziedzinach deficytowych oraz na terenach, na których utrudnione było pełne zaspokojenie potrzeb ludności w swobodnym dostępie do lekarza. Stomatologiczna opieka dzieci w szkołach dotyczyła wszystkich dzieci, bez względu na zatrudnienie rodziców [8].

W stomatologicznej opiece zdrowotnej zmiany dotychczasowego systemu opartego na indywidualnych praktykach prywatnych wpłynęły na konieczność utworzenia nowych jednostek organizacyjnych. Pomieszczenia, w których miały powstać ośrodki zdrowia i przychodnie lekarskie w okresie powojennym, były początkowo budynkami adaptowanymi do celów służby zdrowia, a w miarę powstawania nowych osiedli mieszkaniowych były budowane i wyposażane od podstaw.

Zmiany w systemie opieki zdrowotnej wiązały się z trójstopniowym podziałem referencyjności placówek medycznych. Poziom rejonowy stanowiły przychodnie rejonowe organizowane na osiedlach, w małych miastach, w dzielnicach dużych miast oraz wiejskie ośrodki zdrowia. Rejon liczył do 4000 mieszkańców i był wyznaczany nazwami ulic. Pracujący w nim lekarze dentyści opiekowali się pacjentami przydzielonymi zgodnie z zasadami centralnego kierowania wg ulic należących do rejonu leczniczego [2]. Rozwijające się od 1953 r. szkolne i międzyszkolne poradnie stomatologiczne wchodziły w skład pierwszego poziomu referencyjnego. Podstawową opiekę dentystyczną w miejscu nauczania zapewniali lekarze dentyści, którzy byli zatrudnieni w poradniach rejonowych, na terenie których znajdowała się placówka szkolna. Osoby, które korzystały z opieki zdrowotnej w miejscu nauczania [2], zachowywały uprawnienia do świadczeń w miejscu zamieszkania. Dokumentacja medyczna pacjenta znajdowała się w miejscu realizacji świadczeń zdrowotnych [9].

Poziom środkowy tworzył zespół stomatologicznych przychodni specjalistycznych zgrupowanych w przychodni obwodowej. Obwód zapobiegawczo-leczniczy stanowił obszar zamieszkały przez ok. 30 000-150 000 mieszkańców; mógł obejmować jedno lub więcej miast i sąsiednie gminy [10]. W obrębie obwodowych przychodni specjalistycznych wyodrębniano: przychodnie chirurgii stomatologicznej, stomatologii zachowawczej, stomatologii dziecięcej, ortodoncji i protetyki stomatologicznej. W późniejszym okresie również poradnie parodontologii [11]. 
Poziom najwyższy stanowiły stomatologiczne przychodnie specjalistyczne szczebla wojewódzkiego [12]. Zatrudniały one zespół specjalistów w dziedzinie stomatologii zapewniający fachową opiekę nad mieszkańcami całego województwa. Sprawowały również funkcje konsultacyjne dla lekarzy z terenu oraz pełniły rolę szkoleniową i nadzorczą.

Najmniejszym zakładem opieki zdrowotnej były ośrodki zdrowia [4]. W skład każdego ośrodka zdrowia wchodziły poradnie: internistyczna, ginekologiczna, chirurgiczna i stomatologiczna. Poradnie pełniły też rolę profilaktyczną. Przychodnie stanowiły jednostki służby zdrowia zajmujące się leczeniem [13]. Na powiatach, związkach samorządu terytorialnego spoczywał obowiązek zakładania i utrzymywania okręgowych ośrodków zdrowia. Obejmowały one swą działalnością jedną lub więcej gmin. Działalność ośrodków okręgowych uzupełniały powiatowe ośrodki zdrowia. Państwo zakładało i utrzymywało również zakłady lecznicze o charakterze specjalistycznym [4] obejmujące obszar całego województwa [7].

Powstawały również przychodnie lekarskie, w tym przychodnie stomatologiczne. W jednym budynku mieściło się wówczas kilka poradni, wśród których znajdowały się poradnie stomatologii dziecięcej, zwane również poradniami międzyszkolnymi.

Na przełomie lat 40. i 50. XX w. rozszerzono opiekę stomatologiczną na dzieci i młodzież w miejscach nauczania i wychowania. Porozumienia zawarte pomiędzy Zakładem Ubezpieczeń Społecznych a Ministrem Pracy i Opieki Społecznej oraz Ministrem Oświaty wprowadziły dla dzieci uczących się możliwość korzystania z opieki stomatologicznej w szkołach. Odbywała się ona na następujących zasadach:

1. „Ubezpieczalnia Społeczna urządzała gabinety dentystyczne w szkołach stosownie do liczby uczniów. Młodzież ucząca się w okolicznych szkołach korzystała z udostępnionego gabinetu w placówkach, w których gabinety zostały utworzone w pierwszej kolejności.

2. W mniejszych miejscowościach młodzi ludzie korzystali z możliwości leczenia w gabinetach dla dorosłych.

3. W kosztach utrzymania gabinetu, w wynagrodzeniu personelu, kosztach leków i materiałów dentystycznych oraz w finansowaniu opieki dentystycznej nad dziećmi nieobjętymi ubezpieczeniem partycypowały kuratoria, dyrekcje szkół, samorządy, koła rodzicielskie.

4. Całkowita sanacja jamy ustnej miała nastąpić przed ukończeniem nauki w szkole" $[3,5,14]$.

Rozszerzenie opieki stomatologicznej nad dziećmi i młodzieżą szkolną wiązało się ściśle z kierunkami rozwoju opieki medycznej nad matką i dzieckiem wpisującymi się w zakres planów gospodarczych - 6-letniego i 5-letniego realizowanych w latach 1949-1960 [15].

W latach 70. XX w. nastąpiło połączenie lecznictwa otwartego i zamkniętego. Na skutek koniunkcji powstały zakłady opieki zdrowotnej podległe strukturalnie pod szpital wojewódzki. W ramach zintegrowanych zakładów opieki zdrowotnej funkcjonowały stomatologiczne zakłady profilaktyczno-lecznicze, które udzielały świadczeń opieki zdrowotnej w zakresie stomatologii zachowawczej, pedodoncji, ortodoncji, chirurgii stomatologicznej i protetyki [5]. Mająca wówczas miejsce ogólna poprawa warunków bytowych i sanitarnych wpływała na poprawę higieny jamy ustnej, podniesienie poziomu oświaty stomatologicznej, rozwój działań profilaktycznych poprzez opiekę nad matką i dzieckiem, rozwój szkolnych i międzyszkolnych poradni stomatologicznych oraz rozwój egzogennej profilaktyki fluorkowej i leczenia planowego u dzieci i młodzieży. Miało to wpływ na poprawę stanu zdrowia jamy ustnej mieszkańców miasta [5].

Pogłębiający się w latach 1980-1989 kryzys ekonomiczny doprowadził do zapaści systemu ochrony zdrowia związanej z poszerzaniem się liczby osób objętych opieką zdrowotną bez równoczesnego wzrostu środków finansowych na realizację zadań.

Zielona Góra znajduje się na terenach tzw. Ziem Odzyskanych przez Polskę po II wojnie światowej. Specyfika opieki stomatologicznej w mieście wiązała się z koniecznością stworzenia całego systemu stomatologicznej opieki zdrowotnej od podstaw. W skład systemu opieki zdrowotnej wchodziły m.in.: infrastruktura wraz z pomieszczeniami adaptowanymi na cele stomatologicznej opieki zdrowotnej, sprzęt i materiały stomatologiczne oraz lekarze dentyści, którzy przyjeżdżając do miasta, mieli wrażenie tymczasowości związanej z ryzykiem utraty nowych ziem zachodnich przez Polskę, ale przede wszystkim chcieli powrotu m.in. na kresy wschodnie i do Polski centralnej, bo mieli tzw. nakazy pracy, które danego lekarza obowiązywały kilka lat.

Przybywający do miasta wraz z ludnością napływową pierwsi lekarze dentyści rekrutowali się z kadr wykształconych przed wojną. Dopiero pod koniec lat 40. XX w. na tereny tzw. ziem odzyskanych zaczęli napływać lekarze dentyści, którzy ukończyli studia stomatologiczne w pierwszych latach powojennych. Przyjeżdżali oni do Zielonej Góry na podstawie nakazów pracy $[5,16]$ wydanych w trybie nakazowo-rozdzielczym, zgodnie z ustawą o społecznych zakładach służby zdrowia i planowej gospodarce w służbie zdrowia [4]. Wśród przybyłych do miasta absolwentów poznańskiej akademii medycznej była m.in. lekarz dentysta Heliodora Setna-Dolecka. Była ona pierwszą osobą, która w latach 70. XX w. uzyskała specjalizację ze stomatologii dziecięcej [5]. Początkowo pracowała w przychodni stomatologicznej dla dzieci przy al. Niepodległości 16. Doktor Dolecka w kolejnych latach pracowała w gabinecie stomatologicznym w szkole specjalnej, gdzie dzieci wymagały szczególnej troski i opieki. Była oddana, życzliwa i serdeczna dla pacjentów oraz koleżanek i kolegów, za co była powszechnie ceniona i lubiana. Przepracowała w zielonogórskim lecznictwie dziecięcym ponad 50 lat [17]. Była niekwestionowanym wzorcem dla wielu lekarzy w owych czasach. Tacy lekarze także w czasach obecnych, czasach pewnej dehumanizacji medycyny, są szczególnie potrzebni. Wraz z dr Dolecką opiekę stomatologiczną nad dziećmi sprawowali lekarze dentyści: Ewa Rudnicka-Cedro, Irena Izydorczyk-Konecka [18], Halina Bereżecka-Cegielska [18], Maria Idaszewska [18], Wanda Żytkiewicz i Zofia Bąbol-Pawlak oraz uprawniony technik dentystyczny Teofil Orpel [5]. Irena Konecka (1929-2005) ukończyła Akademię Medyczną w Poznaniu w 1953 r. Nakazem pracy została 
skierowana do Zielonej Góry [18]. Po śmierci została pochowana na cmentarzu komunalnym w Zielonej Górze. W trakcie wieloletniej pracy uzyskała specjalizację z zakresu stomatologii zachowawczej. Uczestniczyła w pracach oddziału Polskiego Towarzystwa Stomatologicznego w Zielonej Górze. Zawsze spokojna, sumienna, opanowana, życzliwa, zyskała sobie zaufanie i wdzięczność pacjentów [5, 18, 19]. Halina Bereżecka-Cegielska (ur. w 1925 r.) ukończyła Akademię Medyczną w Poznaniu w 1953 r. Nakazem pracy została skierowana do Zielonej Góry, gdzie podjęła pracę $w$ poradni lekarsko-dentystycznej dla dzieci przy al. Niepodległości [5, 18]. Maria Idaszewska (ur. w 1919 r.) ukończyła Akademię Medyczna w Poznaniu w 1953 r. Osiedliła się w Śremie. Podjęła pracę w poradni lekarsko-dentystycznej dla dzieci przy al. Niepodległości $[5,18]$.

Poradnia Lekarsko-Dentystyczna (PLD) dla dzieci mieściła się w obwodowym ośrodku zdrowia, w budynku nr 16 przy al. Generalissimusa Stalina, przemianowanej następnie na al. Niepodległości.

Poradnia Lekarsko-Dentystyczna dla dzieci pozostawiała wiele do życzenia, o czym świadczyły wyniki kontroli. W trakcie jednej z nich, przeprowadzonej przez członków Wojewódzkiej Komisji Zdrowia, wskazano na wiele uchybień. Kontrolujący podkreślali, że lokal przeznaczony na przychodnię dentystyczną dla dzieci nie jest całkowicie przygotowany do przyjęć małych pacjentów. Stwierdzono brak tablic informacyjnych, brak kancelarii, zaś w poczekalni zbyt małą liczbę krzeseł i wieszaków oraz brak stolika dla dzieci. Poza tym stwierdzone warunki sanitarne w poczekalni określano jako złe. W przychodni nie było możliwości ciągłego poboru wody (dostępna była jedynie okresowo). W celu płukania ust i do mycia rąk przynoszono wodę w brudnej miednicy (odnotowano brak specjalnego naczynia na wodę). Spluwaczka, do której usuwa się wodę z ust, była brudna, ze śladami krwi z poprzedniego dnia [20].

W latach 1962-1989 poradnia stomatologiczna dla dzieci oraz poradnia międzyszkolna zlokalizowane były na pierwszym piętrze przychodni stomatologicznej przy ul. Bankowej 1a, gdzie znalazły się po przeprowadzonym remoncie [5]. W przychodni były już trzy fotele. Czas oczekiwania w poczekalni na przyjęcie, z uwagi na dużą liczbę pacjentów, wynosił niejednokrotnie kilka godzin [20].

W szkolnych gabinetach stomatologicznych, podlegających strukturalnie poradniom, pacjenci byli przyjmowani przez 6 godz. dziennie w okresie od września do czerwca. Prowadzono leczenie planowe dzieci oraz zabiegi profilaktyczne połączone z prowadzeniem przez lekarzy dentystów pogadanek profilaktycznych [5]. W okresie wakacyjnym personel stomatologiczny pracujący w szkołach delegowany był do przychodni przy ul. Bankowej celem zwiększenia liczby kadry stomatologicznej, która przyjmowała wówczas wszystkie dzieci zgłaszające się do leczenia z terenu miasta i powiatu.

Wojewódzka Przychodnia Higieny Szkolnej (WPHS) została powołana jako samodzielna jednostka budżetowa w 1961 r. Powstała na bazie Miejskiego Ośrodka Pomocy utworzonego w 1945 r. przy ul. Stalina 18. W dniu 7 listopada 1962 r. na mocy uchwały Prezydium Wojewódzkiej Rady Narodowej w oparciu o Wojewódzką Przychodnię Higieny Szkolnej powstał Wojewódzki Ośrodek Matki i Dziecka [21]. W ramach WPHS funkcjonowały następujące poradnie: kardiologiczna, okulistyczno-ortopedyczna, endokrynologiczna, wad postawy, laryngologiczna, foniatryczna, lekarsko-dentystyczna i ortodontyczna. Oprócz wymienionych poradni w skład przychodni wchodziły ponadto gabinety: fizykoterapii, elektrokardiologii i audiometrii oraz laboratorium analityczne. W ramach działalności Poradni Wad Postawy zorganizowano sekcję gimnastyki korekcyjnej dla dzieci z wadami postawy [21].

Warunki lokalowe przychodni były bardzo trudne. Nie posiadała ona wystarczającego zaplecza lokalowego, budżetowego i kadrowego. Opiekę lekarską nad matką i dzieckiem sprawowało w przychodni 11 lekarzy medycyny, w tym 8 zatrudnionych na niepełnych etatach oraz 2 lekarzy dentystów, w tym 1 zatrudniony w niepełnym wymiarze godzin - lek. dent. Maria Dobrzyńska [5, 21]. Niedostateczna liczba techników dentystycznych wpłynęła na brak możliwości zapewnienia opieki ortodontycznej nad dziećmi. Zatrudniony w niepełnym wymiarze czasu pracy technik nie nadążał z wykonywaniem aparatów ortodontycznych. Pionierką w dziedzinie lecznictwa ortodontycznego w Zielonej Górze była lek. dent. Lucyna Raczyńska [5], pracująca w WPHS od momentu jej utworzenia [5]. Po 1972 r. kadrę ortodontyczną poradni powiększyła lek. dent. Anna Stawiarska [5], a w 1984 r. lek. dent. Henryka Lipińska-Bazan (ryc. 1) [5].

W 1963 r. PLD, wchodząca w skład WPHS, przyjęła w sumie 8419 pacjentów, a poradnia ortodontyczna 162 pacjentów. Oprócz zabiegów wykonywanych bezpośrednio w gabinetach przychodni pracujący w niej lekarze prowadzili akcje profilaktyczne na terenie szkół i przedszkoli miasta oraz powiatu zielonogórskiego. Badania profilaktyczne miały na celu wykrycie nieprawidłowości szczękowo-ortopedycznych i skierowanie dzieci do przychodni celem leczenia ortodontycznego [21]. W latach 60. XX w. wystąpił rozwój wszystkich dziedzin stomatologii, a w szczególności profilaktyki stomatologicznej i ortodontycznej [5, 21]. Poradnia ortodontyczna, która była młodą jednostką przychodni, borykała się z trudnościami zarówno

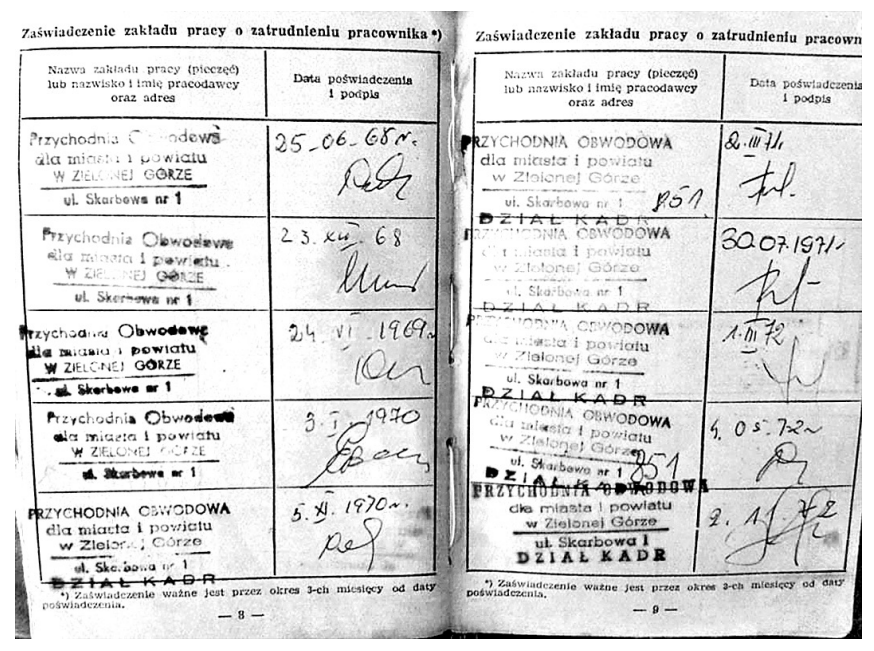

RYCINA 1. Książeczka ubezpieczeniowa potwierdzająca miejsce zatrudnienia lek. dent. Henryki Lipińskiej-Bazan (fot. Jacek Kotuła) 
kadrowymi, związanymi z brakiem technika dentystycznego, jak również brakami zaplecza materiałowego oraz brakiem ścisłej współpracy z kliniką ortodontyczną przy akademii medycznej [21]. Zielonogórska poradnia ortodontyczna była jedną z dwóch poradni funkcjonujących w województwie zielonogórskim. Drugą była szkolna poradnia ortodontyczna w Gorzowie Wielkopolskim [21].

Celem poprawy opieki lekarskiej i lekarsko-dentystycznej nad młodzieżą szkolną oraz poprawy warunków sanitarnych w placówkach nauczania i wychowania WPHS wraz z Kuratorium Okręgu Szkolnego zorganizowały we wszystkich powiatach województwa narady i szkolenia pionu zdrowia i oświaty, w trakcie których omawiano całokształt pracy szkolnej służby zdrowia. Podejmowano próbę oceny zachowania minimum sanitarnego, które oceniono na mniej niż dostatecznie, oraz poziomu opieki lekarskiej i lekarsko-dentystycznej, co nie było zapewnione w niezbędnym wymiarze i zakresie. Brak opieki lekarsko-dentystycznej w szkołach wpływał na wzrost zapotrzebowania na zabiegi stomatologiczne świadczone w WPHS. Również poziom zabezpieczenia stałej lub okresowej opieki lekarskiej w szkołach pozostawiał wiele do życzenia. Niektóre szkoły w mieście (szkoła na Chynowie) oraz szkoły wiejskie były pozbawione opieki lekarskiej [5, 21], a w szkołach o zapewnionej opiece jej jakość była na niskim poziomie. W jednej ze szkół podstawowych znajdującej się na Osiedlu Piastowskim pracowała do 1972 r. lek. dent. Anna Stawiarska, która oprócz profilaktyki stomatologicznej i planowego leczenia stomatologicznego dzieci i młodzieży prowadziła również profilaktykę ortodontyczną [5, 21]. W wielu szkołach podstawowych i średnich w związku z licznymi brakami kadrowymi nie było dostatecznej obsady lekarsko-stomatologicznej [22]. Zły stan zdrowia społeczeństwa bywał zagrożeniem dla zdrowia personelu lekarsko-dentystycznego. Częste zachorowania lekarzy dentystów utrudniały dostęp do świadczeń zdrowotnych nawet w szkołach, w których lekarze byli zatrudnieni [22].

Warunki sanitarne panujące w szkołach województwa zielonogórskiego określano na podstawie kontroli prowadzonych przez Wojewódzką Stację Sanitarno-Epidemiologiczną i Wojewódzką Przychodnię Higieny Szkolnej. Były one na dalece odbiegające od norm Ministerstwa Zdrowia i Oświaty [21].

W poradni ortodontycznej wchodzącej w skład Poradni Higieny Szkolnej w latach 70. XX w. oprócz lek. dent. Lucyny Raczyńskiej pracowała lek. dent. Anna Stawiarska [5, 21]. Pod nadzorem konsultanta wojewódzkiego, którego funkcję pełniła dr Maria Pierczyńska [5], będąca pracownikiem naukowym Akademii Medycznej we Wrocławiu, odbywało się leczenie ortodontyczne pacjentów, profilaktyka ortodontyczna oraz szkolenie kadry ortodontycznej zatrudnionej w Zielonej Górze [5]. W tym czasie funkcję konsultanta wojewódzkiego w dziedzinie ortodoncji pełniła prof. dr hab. n. med. Barbara Perzyna z Akademii Medycznej w Poznaniu [5].

Pomimo trudnej sytuacji lecznictwa stomatologicznego umiejętność prawidłowej organizacji pracy umożliwiała objęcie opieką profilaktyczną i specjalistyczną opieką ortodontyczną dzieci uczęszczających do żłobków, przedszkoli i początkowych klas szkoły podstawowej przez zaledwie jednego lek. dent.
Annę Stawiarską [5]. Plan pracy profilaktycznej z dziećmi obejmował pogadanki w grupach dziecięcych z instruktażem higieny jamy ustnej, omówienie zasad prawidłowego i racjonalnego odżywiania się, odzwyczajanie dzieci od nawyków i parafunkcji negatywnie wpływających na rozwój zębów i narządu żucia. Równolegle do edukacji dzieci prowadzona była intensywna edukacja nauczycieli wychowawców i rodziców określająca kierunki rozwoju prawidłowej higieny jamy ustnej, zasad racjonalnego żywienia, eliminacji parafunkcji i dysfunkcji narządu żucia. Eliminowano nieprawidłowy tor oddychania, nieprawidłowy sposób połykania, które stanowiły główne przyczyny powstawania licznych wad zgryzu w okresie przedszkolnym i wczesnoszkolnym [5]. Praca u podstaw, którą inicjowali lekarze, przynosiła wymierne skutki w postaci licznych pacjentów zgłaszających się na leczenie ortodontyczne i profilaktykę ortodontyczną w poradni profilaktyki ortodontycznej znajdującej się w przychodni w Zielonej Górze przy al. Niepodległości 16 [5].

Potrzeby w lecznictwie ortodontycznym były ogromne. Badania przesiewowe populacji dzieci szkolnych umożliwiły szybkie zdiagnozowanie wszystkich osób wymagających intensywnego leczenia ortodontycznego już we wczesnym okresie życia. Zastosowanie mioterapii, reedukacji toru oddechowego i sposobu połykania, diagnostyki laryngologicznej przeszkód oddechowych, zastosowanie płytki przedsionkowej we wczesnym etapie leczenia wpływało na znaczną eliminację skomplikowanych wad zgryzu u dzieci w późniejszym okresie rozwojowym. Niestety, konieczność leczenia przy użyciu aparatów ruchomych wiązała się z sięgającym nawet kilka lat okresem oczekiwania [5].

System opieki zdrowotnej w Polsce zapewniał bezpłatną opiekę zdrowotną, która wiązała się z brakiem możliwości współfinansowania leczenia oraz reglamentowania specjalistycznych świadczeń stomatologicznych. W związku z brakiem środków kontroli i restrykcji związanych z nierespektowaniem ordynacji lekarskich rodzice nie ponosili żadnych kosztów. Brak wyleczenia poszczególnych jednostek chorobowych, mimo zastosowania sprawdzonych metod, był związany z niesumiennym noszeniem aparatów ruchomych i niedostosowaniem się do ordynacji lekarskich [5].

Analiza działalności służby zdrowia w Zielonej Górze i na terenie województwa zielonogórskiego przez Komisję Zdrowia Wojewódzkiej Rady Narodowej (WRN) wpłynęła na opracowanie planu działania WRN w zakresie opieki stomatologicznej nad dziećmi szkolnymi [23]. Jego główne zadania skierowane były na zwiększenie liczby poradni szkolnych [24] i międzyszkolnych, wprowadzenie planowego leczenia uzębienia dzieci, szerzenia oświaty sanitarnej w zakresie popularyzacji higieny jamy ustnej i prawidłowego odżywiania [24]. Głównym zadaniem opieki stomatologicznej nad dziećmi i młodzieżą była walka z próchnicą zębów.

Podstawowymi jednostkami organizacyjnymi sprawującymi opiekę stomatologiczną nad dziećmi i młodzieżą były poradnie stomatologiczne dla ogółu ludności zlokalizowane w przychodniach i ośrodkach zdrowia. Występowały również poradnie specjalistyczne dla dzieci i młodzieży w przychodniach 
obwodowych. Wprowadzenie w 1952 r. lekarzy dentystów do szkół i utworzenie gabinetów lekarsko-stomatologicznych w szkołach pozwoliło na przeniesienie większości opieki stomatologicznej nad dziećmi i młodzieżą uczącą się do gabinetów w placówkach nauczania. Ponadto w Zielonej Górze przy ul. Bankowej 1a powstała w 1952 r. poradnia międzyszkolna. Zlokalizowana była na pierwszym piętrze powiatowej przychodni stomatologicznej. W poradni przyjmowane były dzieci, które danego dnia nie mogły zostać przyjęte przez dentystę szkolnego [5]. Doktor Sikora tak wspominała: „Do rejestracji zgłosiła się jedna dziewczynka, która uczęszczała do szkoły podstawowej numer 13. To było w czasach, gdy w szkołach przyjmowali lekarze dentyści".

W zależności od liczby szkół i liczby uczęszczających do nich uczniów w ramach rejonowych poradni stomatologicznych wydzielano odpowiednią liczbę godzin umożliwiających lekarzom dentystom prowadzenie planowego leczenia stomatologicznego u dzieci oraz podstawowej opieki nad dziećmi i młodzieżą, które nie były objęte programem planowego leczenia na terenie szkół [23]. Określenie liczby godzin przyjęć dzieci i młodzieży uzależnione było każdorazowo od liczby zgłaszających się do poradni małych pacjentów oraz frekwencji pacjentów dorosłych. Określenie 5-6 godz. dziennie jako czasu przeznaczonego na przyjęcia małych pacjentów, niejednokrotnie nie zaspakajało potrzeb zapewnienia dostatecznej opieki stomatologicznej nad dziećmi [25].

Rozwój szkolnych i międzyszkolnych poradni stomatologicznych wpłynął korzystnie na objęcie planową opieką stomatologiczną dzieci i młodzieży, dzięki czemu doprowadzono do zahamowania rozprzestrzeniania się próchnicy zębów uznanej za chorobę społeczną [5].

$\mathrm{W}$ połowie lat 50. XX w. w mieście istniało 14 poradni międzyszkolnych [26]. 20 października 1962 r. w trakcie narady szkoleniowej wszystkich lekarzy dentystów kierownik Wydziału Zdrowia i Opieki Społecznej PWRN - dr Stanisław Gura podał wytyczne dotyczące leczenia dzieci i młodzieży w roku szkolnym 1962/1963. W naradzie wzięli udział profesorowie Akademii Medycznej w Poznaniu. Profesor Kazimierz Stawiński wygłosił wykład na temat lecznictwa dziecięcego, a prof. Rudolf Sarrazin omówił wpływ odżywiania na próchnicę zębów [26]. Ponadto PWRN pismem z dnia 5 grudnia $1962 \mathrm{r}$. o numerze XIII - 1/108/62 poleciło wprowadzenie planowego leczenia dzieci szkolnych od klasy pierwszej, poprzez drugie, aż do klasy szóstej w zależności od liczby uczniów i lekarzy dentystów [5, 26]. Ponadto lekarze dentyści zostali zobowiązani do wygłaszania pogadanek na temat higieny jamy ustnej i prawidłowego odżywiania [5, 26]. Stwierdzono, że na planowe leczenie uzębienia korzystnie wpłynie ogłoszenie w Dzienniku Ustaw nr 55 z dnia 5 listopada 1962 r. Rozporządzenia Ministra Zdrowia i Opieki Społecznej w sprawie bezpłatności świadczeń z zakresu zębolecznictwa dla wszystkich dzieci szkolnych i przedszkolnych [27], niezależnie od tego, czy rodzice są ubezpieczeni, czy też nie [23]. „Bezpłatne są świadczenia: opieki zdrowotnej otwartej, udzielane przez gabinety lekarsko-dentystyczne dzieciom i młodzieży, uczęszczającym do przedszkoli i szkół, z wyjątkiem protezowania" [26].
Opiekę stomatologiczną nad dziećmi i młodzieżą szkolną sprawowały poradnie szkolne i międzyszkolne. Liczba tych poradni wg stanu na dzień 30 czerwca 1974 r. wynosiła 119 wobec 28 w 1960 r. Liczba przyjętych dzieci i młodzieży wzrosła ze 132900 w 1960 r. do 498500 w 1974 r. [5].

Podstawowym celem lecznictwa stomatologicznego u dzieci i młodzieży stało się prowadzenie zorganizowanej oraz planowej opieki stomatologicznej zarówno w aspekcie leczniczym, jak i profilaktycznym. Działania te prowadziły do redukcji frekwencji próchnicy zębów. Wzrastała również liczba dzieci z przeprowadzoną sanacją jamy ustnej.

Lecznictwo planowe zaczynano od uczniów klas najmłodszych, a po całkowitym ich wyleczeniu przystępowano do leczenia kolejnych roczników, aż do klas najstarszych, systematycznie kontrolując dynamikę rozwoju procesu chorobowego w klasach młodszych. Maksymalna część dnia pracy lekarza dentysty przeznaczona była na leczenie planowe. Niewielka część poświęcana była na leczenie pozaplanowe, do którego zaliczało się udzielanie pierwszej pomocy w nagłych wypadkach oraz leczenie przypadków ostrych [25].

W tabeli 1 przedstawiono wartości liczbowe planowych zabiegów stomatologicznych przeprowadzonych u dzieci w szkołach województwa zielonogórskiego. Źródłowe dane wskazują na utrzymującą się na poziomie ok. 21000 rocznie liczbę wyleczonych zębów w ramach leczenia planowego. Wskazują również na wzrastającą liczbę dzieci objętych egzogenną profilaktyką stomatologiczną w szkołach [28, 29].

TABELA 1. Liczba dzieci objętych planowym leczeniem stomatologicznym w województwie zielonogórskim $[28,29]$

\begin{tabular}{cccccc} 
Rok & $\begin{array}{c}\text { Ogółem } \\
\text { (w tys.) }\end{array}$ & $\begin{array}{c}\text { Zbadani } \\
\text { (w tys.) }\end{array}$ & $\begin{array}{c}\text { Wymagający } \\
\text { leczenia } \\
\text { (w tys.) }\end{array}$ & $\begin{array}{c}\text { Objeczeni } \\
\text { (w tys.) }\end{array}$ & $\begin{array}{c}\text { Obofilaktyką } \\
\text { fluorkową } \\
\text { (w tys.) }\end{array}$ \\
\hline 1961 & 67,3 & 47,1 & 34,4 & 22,5 & - \\
\hline 1965 & 94,8 & 51,3 & 38,5 & 21,5 & - \\
\hline 1967 & 96,6 & 53 & 37,9 & 22,1 & - \\
\hline 1970 & 97 & 49,5 & 34,9 & 24,8 & - \\
\hline 1978 & 93,1 & 53,9 & 26,7 & 21,6 & - \\
\hline 1980 & 65 & 65 & 28,4 & 22 & 56 \\
\hline 1983 & 66 & 66 & 28,8 & 21,2 & 56 \\
\hline 1989 & 58,3 & 58,3 & 34 & 14,6 & 67,1 \\
\hline
\end{tabular}

Niedostateczne finansowanie opieki stomatologicznej dzieci wpływało na selekcję szkół, w których realizowano leczenie planowe. Takie postępowanie było sprzeczne z obowiązującą zasadą równouprawnienia i swobodnego dostępu do świadczeń opieki zdrowotnej. W szkołach zakwalifikowanych w pierwszym etapie do realizacji planowego leczenia zębów u dzieci doprowadzano do sanacji uzębienia w poszczególnych klasach, rozpoczynając od dzieci klas pierwszych. W efekcie prac osiągano wyleczenie wszystkich dzieci w danej szkole, a programem obejmowano kolejne placówki nauczania [5].

Dane przedstawione w tabeli 1 informują o wzroście liczby dzieci objętych planowym leczeniem do schyłku lat 70. XX w. 
W latach 80. XX w. z racji niewydolności systemu finansowego i gospodarczego nastąpił spadek liczby dzieci objętych opieką w ramach leczenia planowego, a wskaźnik zapotrzebowania na leczenie stomatologiczne dzieci ulegał stopniowemu wzrostowi. Dynamika zmian, odnosząca się do powyższych wskaźników, skłoniła władze do podjęcia próby minimalizacji potrzeb leczniczych i skierowania środków finansowych na profilaktykę stomatologiczną, w ramach której w 1980 r. rozpoczęto egzogenną profilaktykę fluorkową w skali całego województwa [20].

Egzogenną profilaktykę fluorkową w Zielonej Górze rozpoczęto w 1953 r., początkowo u 200 dzieci z pierwszych klas szkół podstawowych. W 1989 r. zabiegami objęto 67100 dzieci w województwie zielonogórskim [5, 20].

Na rycinie 2 przedstawiono graficzny rozkład dynamiki zmian w planowym leczeniu stomatologicznym dzieci w województwie zielonogórskim. Na podstawie analizy wykresu można określić rosnącą w ciągu 30 lat liczbę zbadanych dzieci. Stwierdzono również malejącą w latach 70. XX w. liczbę dzieci wymagających leczenia. Schyłek lat 70. XX w. i cała dekada lat 80. XX w. wykazywały tendencję wzrostu liczby dzieci wymagających leczenia przy systematycznym spadku liczby dzieci wyleczonych i przy spadku wszystkich dzieci zbadanych w tym województwie.

Podstawowe kierunki działania lekarza dentysty w lecznictwie pedodontycznym opierały się na:

- właściwej i wcześnie rozpoczętej kontroli stanu uzębienia dążącej do profilaktyki powikłań próchnicy zębów ze strony miazgi zęba,

- zapobieganiu chorobom ogólnym, z rozpoznaniem niedoborów żywieniowych, oraz substytucji witamin, wapnia i fluoru,

- krzewieniu oświaty zdrowotnej, realizowanej w ramach planu pracy poradni stomatologicznej, opartej na współpracy ze szkolnymi kołami Polskiego Czerwonego Krzyża (PCK), klubami Wiewiórka [30].

W Polsce po raz pierwszy kluby Wiewiórka powstały w 1965 r. przy szkolnych kołach PCK. Początkowo obejmowały swoją opieką dzieci klas pierwszych, drugich, trzecich i czwartych szkoły podstawowej. W latach 70. XX w. działalność ich rozszerzono o dzieci z najstarszych wiekowo grup przedszkolnych. W 1971 r. obejmowały swoją opieką 15000 dzieci w kraju. Kluby Wiewiórka były ewenementem polskim, nie mającym

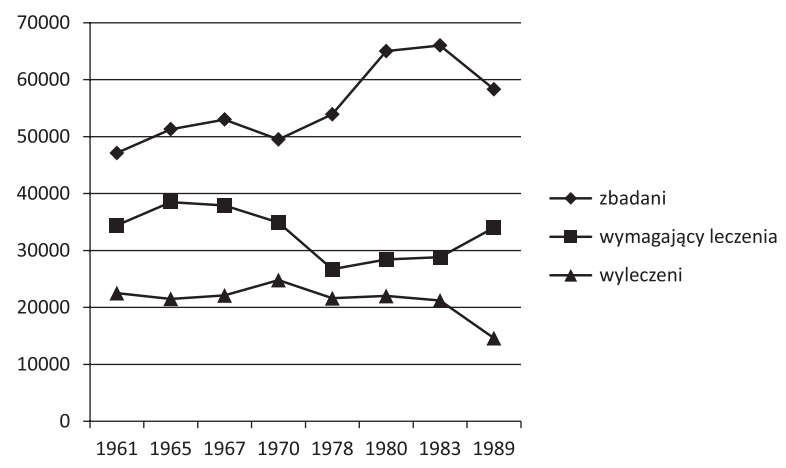

RYCINA 2. Dynamika zmian planowego leczenia dzieci w województwie zielonogórskim odpowiednika w krajach ościennych [30]. Doświadczenia tych jednostek były przyjmowane za granicą z ogromnym zainteresowaniem i uznaniem. Ideą działania były oddziaływania oświatowo-wychowawcze skierowane do dzieci. Przekazywane dzieciom informacji na temat metod szczotkowania zębów, reżimów dietetycznych i regularnych kontroli stomatologicznych oraz doświadczenie kontaktu z otaczającą rzeczywistością, w której dorośli prawidłowo dbają o higienę jamy ustnej i zdrowie uzębienia, wpływały na ugruntowanie wiedzy i kształtowanie postaw przeobrażających się u dzieci w podświadome nawyki realizowane przez całe życie. Wiek przedszkolny i wczesnoszkolny jest okresem, w którym dzieci z łatwością przyswajają informacje poprzez naśladowanie w trakcie zabawy, nauki, zajęć grupowych i indywidualnych.

Symbolem klubu była wiewiórka. Ogromną rolę w funkcjonowaniu klubów mieli nauczyciele i wychowawcy. Profesjonalnie przeszkoleni w dziedzinie profilaktyki próchnicy zębów i zasad higieny jamy ustnej, całkowicie społecznie, przez naukę i kształtowanie pozytywnych postaw wdrażali prawidłowe zasady higieny w codzienne funkcjonowanie dzieci. Należało im się za to ogromne uznanie, gdyż niejednokrotnie wyręczali swoją opieką profilaktyczną rodziców w ich obowiązkach względem dzieci. Zasadniczym celem działania klubów Wiewiórka było ukierunkowanie dzieci na podtrzymywanie zdrowia jamy ustnej, na profilaktykę, wyrabianie zainteresowania stanem zdrowa własnych zębów oraz wdrażanie właściwych zachowań i nawyków zdrowotnych. Opiekunowie klubów, nauczyciele i wychowawcy uczyli dzieci zasad szczotkowania zębów, wyboru najlepszej do wieku szczoteczki i pasty, właściwej częstotliwości oraz odpowiedniego czasu szczotkowania zębów. Propagowali również przestrzeganie odpowiednich reżimów dietetycznych, a przede wszystkim ograniczenie podjadania słodkich przekąsek. Zachęcali do częstych kontroli w gabinecie stomatologicznym i stosowania profilaktyki fluorkowej.

Do zadań klubów należało również: wpajanie podstawowych nawyków higieny osobistej, dbanie o otoczenie i ochronę środowiska, kształtowanie kultury zdrowotnej i humanitarnych postaw w zakresie wrażliwości na potrzeby innego człowieka, pomoc osobom chorym, samotnym, starszym, uczenie prawidłowych zasad współżycia społecznego, a także zasad udzielania pierwszej pomocy [30, 31]. Sukces w działalności klubu stanowiła świadomość jego członków, że są oni odpowiedzialni za zdrowia swoich zębów oraz że od ich aktywnej postawy zależeć będzie stan ich uzębienia i zdrowia [30, 32, 33]. Kluby Wiewiórka organizowały: pokazy i instruktaże prawidłowego szczotkowania zębów, systematyczne, zbiorowe szczotkowanie zębów po śniadaniu i po obiedzie, a także pogadanki i dyskusje prowadzone przez opiekuna klubu. Kluby szkolne współpracowały z przedszkolnymi; np. dzieci ze szkolnego klubu lub koła PCK odbywały wizyty w przedszkolu. Organizowano:

- zbiorowy zakup przyborów do oczyszczania zębów dla członków klubu,

- kącik klubowy,

- wykonywanie gazetek ściennych i plakatów na tematy związane z działalnością klubu, 
- wyświetlanie przeźroczy i filmów o tematyce stomatologicznej,

- quizy i konkursy ustne oraz rysunkowe, łącznie z urządzaniem wystaw rysunków,

- współzawodnictwo i konkursy czystości,

- przedstawienia i inscenizacje o tematyce stomatologicznej,

- gry i zabawy tematyczne mające utrwalać właściwe nawyki higieniczne oraz żywieniowe,

- zamieszczanie artykułów na temat zdrowia zębów w szkolnych gazetkach,

- spotkania z lekarzami dentystami różnych specjalności,

- wystawy o różnej tematyce związanej ze zdrowiem zębów,

- samodzielne wykonywanie drobnych nagród i pamiątek o treści stomatologicznej dla dzieci w przedszkolach,

- Święto Zęba, święta Wiewiórki,

- wymyślanie i rozwiązywanie rebusów, krzyżówek oraz zagadek stomatologicznych [34].

Niestety, mimo intensywnego rozwoju w latach 70. XX w., w późniejszym okresie, ze względu na niezmieniane i niedostosowywane do potrzeb dzieci metody nauczania i formy działania, kluby Wiewiórka stały się mało atrakcyjne dla wychowanków i powoli traciły swoją popularność. Nawet dziś, mimo wykształcenia i zatrudniania znacznej liczby higienistek stomatologicznych, kluby istnieją stosunkowo sporadycznie. Współcześnie są one zastępowane takimi klubami Colgate czy klubami Badaczy kosmosu organizowanymi przez producentów pasty do zębów i akcesoriów stomatologicznych oraz innymi [30, 31].

Kierunki działań lekarzy dentystów miały na celu wyrabianie i utrwalanie wśród dzieci nawyków prawidłowej higieny jamy ustnej, prawidłowego odżywiania, z ograniczeniem podjadania pomiędzy posiłkami głównymi, które powinny zawierać wystarczające ilości składników odżywczych.

Działalność profilaktyczną wspierało postępowanie lecznicze polegające w pierwszej kolejności na eliminacji ognisk zapalnych wpływających na rozwój chorób odogniskowych. Podstawowe działania miały na celu leczenie zachowawcze, a w przypadkach źle rokujących - chirurgiczne ekstrakcje zębów.
W tabeli 2 przedstawiono dynamikę rozwoju lecznictwa stomatologicznego dzieci i młodzieży w Zielonej Górze w latach 1960-1980. Na uwagę zasługuje wzrost liczby foteli dentystycznych (w całym województwie zielonogórskim było ich 340 w 1971 r. [9]), lekarzy dentystów pracujących w lecznictwie pedodontycznym oraz liczby zabiegów wykonanych u dzieci. Jedynie w 1969 i 1980 r. odnotowano spadek wartości poszczególnych zabiegów. Od 1970 r. zauważalna stała się dysproporcja pomiędzy liczbą wypełnień ubytków próchnicowych a liczbą ekstrakcji zębów, co wiązało się ze wzrostem świadomości społecznej odnośnie do zdrowotnych skutków i walorów estetycznych leczonych zębów. W 1980 r. spadła też liczba usuniętych zębów mlecznych [9, 29].

Dane przedstawione na rycinie 3 wskazują na systematycznie wzrastającą liczbę wypełnień zębów oraz malejącą liczbę ekstrakcji zębów stałych u dzieci w Zielonej Górze [5].

Rozwój stomatologicznej opieki zdrowotnej dzieci odbywał się w warunkach ogromnego, niezaspokojonego zapotrzebowania społecznego na tego typu pomoc, dużego deficytu lekarzy dentystów oraz stale powiększającego się zakresu świadczeń stomatologicznych w następstwie rozwoju nauk medycznych [5]. Kryzys ekonomiczny lat 80. XX w. i związane

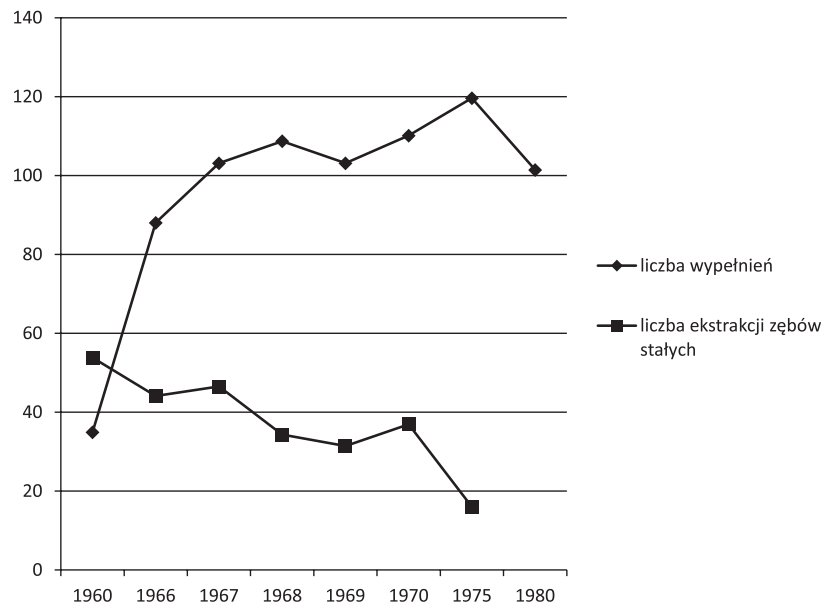

RYCINA 3. Dynamika wzrostu liczby zabiegów w lecznictwie pedodontycznym

TABELA 2. Działalność szkolnych i międzyszkolnych poradni lekarsko-stomatologicznych w Zielonej Górze w latach 1960-1980 [9, 29]

\begin{tabular}{|c|c|c|c|c|c|c|c|}
\hline \multirow{4}{*}{ Lata } & \multirow{4}{*}{ Poradnie } & \multirow{4}{*}{ Fotele } & \multirow{4}{*}{$\begin{array}{l}\text { Lekarze } \\
\text { dentyści }\end{array}$} & \multirow{3}{*}{$\begin{array}{c}\text { Liczba } \\
\text { przyjętych dzieci } \\
\text { i młodzieży }\end{array}$} & \multicolumn{3}{|c|}{ Zabiegi } \\
\hline & & & & & \multirow{2}{*}{ wypełnienia } & \multicolumn{2}{|c|}{ ekstrakcje zębów } \\
\hline & & & & & & mlecznych & stałych \\
\hline & & & & \multicolumn{4}{|c|}{ w tysiącach } \\
\hline 1960 & 28 & 35 & - & 132,9 & 34,9 & \multicolumn{2}{|c|}{53,8} \\
\hline 1966 & 86 & 93 & 85 & 234,2 & 88,0 & 29,9 & 44,1 \\
\hline 1967 & 91 & 93 & 89 & 259,9 & 103,1 & 35,0 & 46,5 \\
\hline 1968 & 105 & 114 & 111 & 284 & 108,7 & 44,3 & 34,3 \\
\hline 1969 & 111 & 120 & 107 & 260,2 & 103,1 & 41,3 & 31,4 \\
\hline 1970 & 104 & 141 & 131 & 305,5 & 110,1 & 40,2 & 36,9 \\
\hline 1975 & - & - & - & 450,8 & 119,6 & - & 16,0 \\
\hline 1980 & - & - & - & 261,3 & 101,4 & 17,7 & - \\
\hline
\end{tabular}


z nim obniżanie finansowania opieki stomatologicznej, szczególnie dotyczące dzieci, doprowadziło do głębokiej zapaści służby zdrowia, która nawet po kolejnych reformach lat 90. XX w. nie potrafiła uzyskać prawidłowych relacji liczby i jakości do celów realizacji świadczeń zdrowotnych.

\section{PIŚMIENNICTWO}

1. Supady J. Historia dentystyki w zarysie. Dentystyka dziecięca. Łódź; 2010. p. 203.

2. Historia stomatologii Piotra Kuźnika. Odc. 1, czyli czym skorupka za młodu. Infodent 24. http://www.infodent24.pl/lifedentpost/historia-stomatologii-piotra-kuznika-odc-1-czyli-czym-skorupka-za-mlodu,5431. html (28.02.2017)

3. Spis abonentów państwowej sieci telefonicznej okręgu krakowskiej dyrekcji poczt i telegrafów wraz z siecią P.A.S.T. w Zagłębiu Dąbrowskim według stanu z dnia 1 stycznia 1929 r. Biblioteka Uniwersytetu Jagiellońskiego, sygn. 66860, poz. 1929 III, s. 32. http://www.muzeumwp.pl/oficerowie /?letter=G\&page=28 (8.03.2017).

4. Ustawa z dnia 28 października 1948 roku o zakładach społecznych służby zdrowia i planowej gospodarce w służbie zdrowia. DzU z 1948, nr 55, poz. 434.p. 1115-22.

5. Kotuła J. Rozwój lecznictwa stomatologicznego w Zielonej Górze w latach 1945-1989 [dissertation]. Łódź: Uniwersytet Medyczny w Łodzi; 2016. p. $23-50$.

6. System ochrony zdrowia. Historia. Ministerstwo Zdrowia. http://www. mz.gov.pl/system-ochrony-zdrowia/powszechne-ubezpieczenie-zdrowotne/historia/ (27.02.2017).

7. Drozdowska U. System organizacji służby zdrowia w Polskiej Rzeczpospolitej Ludowej jako przykład modelu obowiązującego w krajach tzw. obozu socjalistycznego. In: Mróz T, editor. Uwarunkowania systemu opieki zdrowotnej w Polsce. Aspekty prawne i socjologiczne. Białystok: Temida 2; 2012.p. 54-9.

8. Klimek D, Pietras P. Procesy restrukturyzacyjne w sektorze ochrony zdrowia i ich wpływ na zmiany na rynku pracy województwa podlaskiego. Białystok: Wydawnictwo Wojewódzkiego Urzędu Pracy w Białymstoku; 2009. p. 15.

9. Krzyżaniak Z, editor. Rocznik Statystyczny Ochrony Zdrowia 1971. Warszawa: GUS; 1971.

10. Rozporządzenie Ministra Zdrowia i Opieki Społecznej z dnia 19 maja 1982 r. w sprawie organizacji i zadań opieki zdrowotnej. DzU z 1982 r., nr 15, poz. 121. p. 294-6.

11. Fijałek J. Główne etapy i cechy rozwoju podstawowej opieki zdrowotnej w Polsce. Zdrowie Publiczne 1986;97(8):333-9.

12. Frąckiewicz L. Polityka ochrony zdrowia. Warszawa; 1983. p. 145-6.

13. Krajewski-Siuda K, Kociel P. System Zdrowotny II Rzeczypospolitej. Antidotum 2006;2:15-9.

14. Mikliński P. Drogi rozwoju opieki stomatologicznej w Polsce. Mag Stomatol 1997;1(4):42-6.
15. Sztachelski J. Plan sześcioletni w służbie zdrowia. Zdrow Publiczne 1950;12(9):1-48

16. Zgorzalewicz J. Życiorys. Archiwum Oddziału Polskiego Towarzystwa Stomatologicznego w Zielonej Górze. p. 12.

17. Sikora B. Pożegnanie Heliodory Doleckiej. Doktor. Biuletyn Informacyjny Okręgowej Izby Lekarskiej w Zielonej Górze 2009;91(1):25.

18. Spis fachowych pracowników służby zdrowia. Warszawa: PZWL; 1964. p. 412-74.

19. Rajewski St. Irena Konecka - wspomnienie pośmiertne. Doktor. Biuletyn Biuletyn Informacyjny Okręgowej Izby Lekarskiej w Zielonej Górze 2005;76(3):22.

20. Protokoły z posiedzeń, kontroli i plany pracy Komisji Zdrowia WRN w Zielonej Górze. Protokół z przeprowadzonej kontroli lecznictwa otwartego członków Wojewódzkiej Komisji Zdrowia w dniu 23 kwietnia 1954 r. APZG, PWRNZG, sygn. 202, mikrofilm nr: U - 4710. p. 170.

21. Sprawozdanie z działalności Wojewódzkiej Przychodni Higieny Szkolnej za rok 1963 i I kwartał 1964 r. Akta Komisji Zdrowia Wojewódzkiej Rady Narodowej w Zielonej Górze z roku 1964. APZG, PWRNZG, sygn. Or II - 23/2/64. p. 63-4.

22. Pismo Prezydium WRN Wydziału Zdrowia do WRN wydziału Organizacyjnego w sprawie zatrudnienia lekarza dentysty w Liceum Ogólnokształcącym w Zielonej Górze. Protokoły z posiedzeń, kontroli i plany pracy Komisji Zdrowia Wojewódzkiej Rady Narodowej w Zielonej Górze w latach 1955-1956. APZG, PWRNZG, sygn. 212, mikrofilm nr U - 4710. p. 16.

23. Lecznictwo stomatologiczne w województwie zielonogórskim. Powołujące się na pismo nr Zdr. XIII - 1/96/62 z dnia 10.10.1962 r. APZG, PWRNZG, sygn. 1340/II, mikrofilm nr U - 4714. p. 18-9.

24. Informacje o absencji lekarza dentysty w LO nr 1, k. 187. APZG, PWRNZG, sygn. 202, PWRN - komórka organizacyjna.

25. Hładkiewicz E. Opieka stomatologiczna nad ludnością wiejską województwa zielonogórskiego. 40 lat ONZ. Zielona Góra: Polskie Towarzystwo Przyjaciół ONZ; 1985. p. 102-21.

26. Ocena działalności w służbie zdrowia w lecznictwie otwartym. Wystąpienie na PWRN w dniu 20.09.1955 r. APZG, PWRNZG, sygn. 127/II., mikrofilm nr U 4710 - 4714. p. 29.

27. Rozporządzenie Ministra Zdrowia i Opieki Społecznej z dnia 18 sierpnia 1962 r. w sprawie bezpłatności niektórych świadczeń społecznej służby zdrowia. DzU z 1962 r., nr 55, poz. 277, par 2, ust. 2, pkt. c.

28. Krzeczkowska E. Rocznik statystyczny w ochronie zdrowia 1945-1967. Warszawa: GUS; 1969. p. 418.

29. Junak A, editor. Ochrona zdrowia 1971. Warszawa: GUS; 1972. p. 89.

30. Kluby „Wiewiórka”. Przeszłość i teraźniejszość. Higienistka Stomatologiczna 1998;3:21-3. http://www.krajewscy.lublin.pl/publ/kluby.pdf (5.03.2017).

31. Jańczuk Z. Co nowego w stomatologicznej oświacie zdrowotnej? Czas Stomatol 1986;10:669.

32. Jańczuk Z, editor. Wytyczne w sprawie stomatologicznej oświaty zdrowotnej. Warszawa: MZiOS; 1981.

33. Kowalczyk D, editor. Materiały pomocnicze dla opiekunów klubów „Wiewiórka” PCK. Warszawa: PZWL; 1989.

34. Sebastyańska Z, Litwinionek B. Akcja klubów “Wiewiórka” w przedszkolach jako jedna $\mathrm{z}$ form wychowania zdrowotnego realizowanego $\mathrm{w}$ ramach ćwiczeń przez studentów stomatologii. Czas Stomatol 1973;11:1189. 